\title{
A Challenging Issue: Should Medications be Prescribed to Pregnant and Depressed Women?
}

\author{
Nazan Aydın, Elif Oral², Mustafa Güleç
}

ÖZET:

Dikkat çekici bir konu: Hamile ve depresyondaki kadınlara ilaç önerilmeli mi?

\begin{abstract}
Erkeklere kıyasla kadınlar daha fazla depresyon yaygınlık oranlarına sahiptir ve özellkle dog̃urganlık çag̃ında depresyona daha da duyarlıdırlar. Depresyon oranları gebelik dönemindeki kadınlar için \%20'lere kadar ulașabilir. Aslında kadınları tedavi eden bir klinisyenin, kendisini annenin ve bebeg̃in gelișiminin korunması için en uygun yöntemi seçmeye çalıșırken bulması oldukça muhtemeldir. Emniyet konuları ve dog̃umla ilgili olumsuz sonuçlar gebelikte antidepresan kullanımı ile ilgili bașlıca endişe alanlarıdır. Dig̃er taraftan, tedavi edilmemiș depresyon da anne ve bebek için sag̃lık komplikasyonlarına yol açma potansiyeline sahiptir. Ancak gebelikte antidepresan kullanımının muhtemel yan etkilerinin daha fazla vurgulandig̃ı ama tedavi edilmemiș depresyonun o kadar önemsenmedig̃i aşikardır. Halihazırdaki çalıșmalar gebelik sırasında antidepresan kulIanımının emniyetli olup olmadı̃ãna dair çelișkili sonuçlar ortaya koymaktadır dolayısıyla da mevcut verilerin yorumlanması çok dikkatli bir şekilde yapılmalıdır. Ebeveynlerle birlikte karar verirken her iki seçeneg̃in de riskleri ve faydaları göz önüne alınmalıdır.
\end{abstract}

Anahtar sözcükler: Gebelik, antidepresan emniyeti, teratojenite, tedavi edilmemiș depresyon
ABSTRACT:

A challenging issue: Should medications be prescribed to pregnant and depressed women?

Women have higher prevalence rates of depression than men and they are particularly vulnerable to depression in childbearing years. The rates of depression can reach up to $20 \%$ of all women during pregnancy. Actually, physicians who treat women are likely to find themselves trying to choose the best option for protection of the mother and for the development of her child. Safety issues and negative birth outcomes are matters of concern with antidepressant use during pregnancy. Otherwise, untreated depression also has potential to cause health complications for both mother and infant. It is obvious that possible adverse effects of antidepressant use during pregnancy are more emphasized but adverse outcomes of untreated depression are underrated. Currently, studies exhibit conflicting results about antidepressant safety in pregnancy period so current data must be cautiously interpreted. The risks and benefits of both options must be taken into account in decisionmaking process with families.

Key words: Pregnancy, antidepressant safety, teratogenicity, untreated depression

Journal of Mood Disorders 2011;1(3):118-25
${ }^{1} \mathrm{MD}$, Professor, Atatürk University, Medical Faculty, Department of Psychiatry, Erzurum-Turkey

${ }^{2} \mathrm{MD}$, Assistant Professor, Atatürk University, Medical Faculty, Department of Psychiatry, Erzurum-Turkey

Yazıșma Adresi / Address reprint requests to: Nazan Aydın, Atatürk University, Medical Faculty, Department of Psychiatry, Erzurum-Turkey

Telefon / Phone: +90-442-231-6951

Faks / Fax: +90-442-236-1301

Elektronik posta adresi / E-mail address: nmda25@gmail.com

Kabul tarihi / Date of acceptance 2 Eylül 2011 / September 2, 2011

Bag̃ıntı beyanı:

N.A., E.O., M.G.: Yazarlar bu makale ile ilgili olarak herhangi bir çıkar çatıșmas bildirmemișlerdir.

\section{Declaration of interest:}

N.A. E. . M.G. The authors reported no conflict of interest related to this article.

\section{Journal of Mood Disorders 2011;1(3):118-25}

\section{INTRODUCTION}

Pregnancy and medical treatment have always been a concern in both medical and public minds. Health professionals engaged in women's healthcare quite often struggle with the decision to find the best option. Pregnancy represents a time of high risk for exacerbation of mental illness in particular. $10 \%$ to $15 \%$ of women in the reproductive period experience depression during pregnancy and the postpartum period (1). Though treatment of depression during pregnancy often has been debated, antidepressant use during pregnancy was accepted as relatively safe prior to 2005, when FDA released the warning about Paroxetine. In September 2009, Glaxo Smith Kline was punished with a \$2.5 million fine to be paid to parents of a boyborn with a cardiovascular disease following in utero exposure to Paroxetine. This outcome has skyrocketed the worries about the usage of antidepressant drugs by pregnant women. The discussion focuses especially on safety, birth outcome, health complications, and developmental effects of antidepressant drugs. Those who do not recommend antidepressant treatment emphasize the negative findings of studies on infant development and maternal health. On the other hand, if medication treatment is necessary and not offered, are not there risks? Untreated depression also 
has negative consequences on birth outcome, infant and mother health and development. So a depressed pregnant woman and her baby should be kept in mind. Case reports and some research referenced by opponents of antidepressant use not only have conflicting results but also have some methodological problems. Correct interpretation of data and consideration of the possible risks are essential to provide appropriate therapeutic intervention for depressed and pregnant women.

\section{Opponent Arguments About Antidepressant use During Pregnancy}

The potential risks attributed to antidepressant use during pregnancy are risk of organ malformation or teratogenesis, risk of fetal loss or miscarriage, risk of neonatal toxicity or withdrawal syndromes during the acute neonatal period, and risk of long-term neurobehavioral sequelae (2).

The first Tricyclic Antidepressants (TCA) was marketed in 1958. Early reports about the antidepressant teratogenicity included a child with limb deformities who had been exposed in utero to TCA (3). This case was caused widespread fear of antidepressant use in pregnancy and drew attention to the teratogenicity of antidepressants for the first time. Recently, Selective Serotonin Reuptake Inhibitors (SSRI), relatively newer and more commonly prescribed antidepressants, also have been investigated. Recent studies have indicated an increased prevalence of congenital malformations, for example anencephaly, omphalocele, craniosynostosis, and more consistently heart defects $(4,5)$. Some research has suggested an increased risk of heart defects, especially with Paroxetine but also Sertraline, Fluoxetine, and Citalopram. Sertraline has been found to be related to right ventricle outflow obstruction (5). Paroxetine has been associated with increased risk for cardiac defects, especially atrial and ventricular septal defects. (6). According to this study, increased risk for major malformation is $1 \%$ over the baseline risk and for cardiac defects is $2 \%$ over. Based on these findings, Paroxetine has been labeled as risk category $\mathrm{D}$ (there is evidence of risk in human but the drug may have benefits that outweigh the risk) from $\mathrm{C}$ (animal studies show risk but there are no controlled studies in humans; or studies in animals and humans are not available) by the FDA (Food and Drug Administration). A recent study from Finland provides more evidence that exposure to selective serotonin reuptake inhibitors (SSRIs) in the first trimester of pregnancy increases the risk for major congenital anomalies, particularly cardiac defects (7). In the study, use of Fluoxetine in early pregnancy was associated with about a 2-fold increased risk for isolated ventricular septal defects, whereas Paroxetine was associated with more than a 4 -fold increased risk for right ventricular outflow tract defects. In this study, Malm et al. noted that the absolute risk for these specific cardiac anomalies is small: $0.5 \%$ and $0.2 \%$, respectively, and they suggested that "clinicians not to consider Fluoxetine or Paroxetine as the first option when prescribing an SSRI to women planning pregnancy."(7).

The second attributed risk of antidepressant use during pregnancy deals with the outcome of the pregnancy. Some studies have reported an increased rate of spontaneous abortions in the antidepressant-exposed groups compared with the nonteratogen-exposed groups. A small but statistically significant risk of low birth weight and premature birth also has been reported. Neonatal symptoms related to antidepressant use during late pregnancy have been observed such as respiratory distress, jitteriness, hypoglycemia, irritability, increased REM sleep, hypotonus, and rarely seizure and cardiac rhythm anomalies (8-10). Recently attention has focused on Persistent Pulmonary Hypertension (PPH) associated with exposure to SSRIs after 20 weeks of pregnancy (11).

The third argument against the use of antidepressants during pregnancy is the potential for long-term neurodevelopmental abnormalities, including cognitive and language impairment and behavioral teratogenesis. Some scientists say, "we always predicted that developmental exposure to these drugs would have some deleterious effects." (12). A study on birth outcomes and postnatal neurodevelopment function between ages 6 and 40 months found that lower APGAR scores and lower motor development scores in infants exposed to SSRIs compared with non-exposed children (13). An attenuated response to heel prick pain has also been shown in infants with prenatal SSRI exposure compared with unexposed infants (14). Animal research has shown that early exposure to SSRIs produces selective behavioral changes in adult rats, including increased locomotor activity and decreased sexual behaviour (15). A recent article published in the Archives of General Psychiatry reported an 
association between autism and maternal SSRI use during pregnancy. The authors conducted a case controlled study of a Kaiser Permanente database. They reported a greater risk of autism spectrum disorders among children of SSRI users compared to non-users during pregnancy (16).

\section{Rebuttals to Arguments Against Antidepressant use During Pregnancy}

Teratogenicityis described as congenitalabnormalities or organ malformations that occur over the population baseline rates. The baseline risk of congenital abnormality is $1-3 \%$ for general population (17). Since first data about teratogenicity of TCA use, 3 prospective and more than 10 retrospective studies have been conducted on first trimester TCA use (18-21) and none of them reported congenital abnormalities were over baseline.

SSRIs have been reported as causative factor for congenital malformations. The best-studied SSRI, Fluoxetine, has been examined with 5 recent prospective and 4 retrospective studies (18,22-26). Data obtained over 2500 case (531 first trimester) could not find any increased risk above the 1-3\%. Recently some SSRIs, especially Paroxetine, have been associated with increased risk with cardiac defects. Data about Paroxetine have been based on a retrospective cohortstudy conducted by manufacturer of Paroxetine, GSK (6). According to this study, increased risk for major malformation is $1 \%$ over the baseline risk and for cardiac defects is $2 \%$ over. However, this study has some limitations including retrospective design, use of post-hoc analyses to obtain the adjusted odds ratios for cardiovascular malformations and congenital malformations, lack of matched control group, and limited clinical data such as severity of depression (21). Other studies about Paroxetine did not confirm those findings $(27,28)$. SSRIs have only been associated with cardiac abnormalities in retrospective studies. Some case reports and epidemiological studies for other SSRIs and another group of antidepressants also did not find any association for increased risk (27,29-31). Two landmark large-scale case-control studies demonstrated that overall SSRI exposure was not associated with congenital cardiac or a majority of other categories of birth defects. Current data on SSRI exposure, including Paroxetine, show no consistent information to support specific morphological teratogenic risks. Most recently, Malm et al. issued a warning about Fluoxetine and Paroxetine saying it, "should not be a first option in women planning to become pregnant." Authors also claimed, "For individual SSRIs, Fluoxetine and Paroxetine were associated with an increased risk for overall major congenital anomalies and cardiovascular anomalies in the crude analysis, but the risk did not remain statistically significant after adjusting for confounding factors." (7). Also, a large number of comparisons might have resulted from the possibility that some of the observed associations might reflect variation by chance. Though there are conflicting results, none of congenital abnormalities attributed to antidepressants have been reported in prospective controlled studies and meta-analysis of these studies. Therefore, reports about teratogenicity of antidepressants during pregnancy must be cautiously evaluated.

The available literature points to an increased risk of negative birth outcomes and neonatal complications. Some studies have reported an increased rate of spontaneous abortions in the antidepressant-exposed groups compared with the nonteratogen-exposed groups. However, these rates of spontaneous abortions have not exceeded the reported $10-20 \%$ baseline rate in the general population (18). Although a small but statistically increased risk of low birth weight and premature birth has also been reported, only 1 week early birth has been observed in women who were exposed to antidepressants late in pregnancy. A one-week premature delivery is acceptable even if connected with other pregnancy problems. Neonatal symptoms attributed to antidepressant use during late pregnancy have been described as transient (starting with minutes and limited to several days following delivery), mild and usually not requiring clinical intervention (14). Recently attention has focused on Persistent Pulmonary Hypertension associated with exposure to SSRI after 20 weeks of pregnancy. Though there have been conflicting results, the reported risk is about $1 \%$ of this severe but rare complication (11).

There is a limited amount of data regarding the longterm effects temperament, behavior, reactivity, mood, distractibility, and activity level among groups when followed through early childhood. No difference has been detected in behavioral or cognitive development in children exposed to Fluoxetine, TCAs or without medication, in terms of IQ, language, temperament, 
behavior, reactivity, mood, distractibility, and activity level among groups when followed through early childhood $(27,32,33)$. Some studies of post-birth development of children exposed in utero to SSRI have been published. All converge on the finding that mental development (on the Bayley Scales of InfantDevelopment) was found to be similar in exposed compared to nonexposed children. A slight delay (within normal limits) of achievement of motor milestones in children exposed during gestation to SSRI has been reported, but no differences have been observed between the exposed and control groups at 19 months (13). Although some animal studies have showed that early exposure to SSRIs might disrupt the normal maturation of the serotonin system and could alter serotonin-dependent neuronal processes, it is not known whether these effects are also seen in humans. A recent article published in the Archives of General Psychiatry reported an association between autism and maternal SSRI use during pregnancy (16). The authors included diagnoses of autism spectrum disorders, maternal lifetime psychiatric history, and SSRI and other antidepressant prescriptions dispensed during pregnancy in the analyses. Maternal depression symptoms and burden of illness during pregnancy have not been evaluated. It is not clear whether the mothers maintained antidepressant treatment or not. Therefore, these data are limited. Further, more definitive investigation into the long-term neurobehavioral effects of prenatal exposure to antidepressants is required.

\section{The Other Side of The Coin}

For the sake of protecting the infant and mothers, many physicians and mothers immediately discontinue the antidepressant treatment as soon as the conception has been noticed. Abrupt discontinuation of antidepressants may cause withdrawal syndrome which characterized with nausea and vomiting, diarrhea, diaphoresis, hot or cold flashes, tremors, excess lacrimation, syncope, anxiety, panic attacks, low energy, fatigue, and mood swings (30). Most critically, sudden discontinuation of antidepressants has been associated with relapse of the underlying psychiatric condition (34). Relapse risk is 5 times higher in women with recurrent or resistant depression who have stopped antidepressant treatment during pregnancy (35). Moreover, many people believe that pregnancy has a protective and curative effect on depression. Pregnancy does not have a protective effect (35) therefore; it means that both mother and infant will be exposed to the negative influences of untreated depression. What are the consequences, if a pregnant woman has been untreated? It is well known that especially chronic and repetitive stress results in higher cortisol levels. Depression as an important source of stress may lead to increased cortisol levels, insulin resistance, and gestational diabetes. In addition, depression during pregnancy has been associated with pregnancy induced hypertension and pre-eclampsia (36). In experimental animal studies, the effects of stress on the brain development of rats who were born with depressed mothers have been investigated and following results have been obtained: Lower BDNF and S-100B levels (meaning a decrease in neurogenesis and synaptogenesis), decreased hipocampal volume, increased Caspase-3 activity (meaning an increase in apoptosis), lower 5-HT1A receptor activity in the ventral hippocampus, and tendency to display an anxiety-depression behavior in adulthood when they are confronted with stress (37). Occasionally, depression not only leads to functional impairment but also causes deleterious behaviors as selfmedication, use of alcohol, substance abuse, smoking, poor nutrition, and inadequate weight gain, all of which are harmful to both the mother and infant's health. In addition, lack of motivation and self-esteem may result in inadequate prenatal care. (36,38-43). The most notable adverse pregnancy outcomes associated with antenatal depression include increases in spontaneous preterm delivery, low birth weight, and small gestational age (4451). Recent investigations have shown that infants born to depressed mothers tend to exhibit excessive crying, lower orientation scores, inferior excitability, and few expressions of interest shortly after birth, indicating the possibility of neurodevelopmental consequences of maternal depression in the newborn $(48,52)$. A long-term follow up study (11 and 18 years) showed that children of depressed mothers exhibit lower IQ scores and, more violent behaviors $(53,54)$. The profound impact of maternal depression on the health and well-being of children was recently documented in a multi-site study of children of mothers who were treated with medication as part of the Sequenced Treatment Alternatives to Relieve Depression (STAR*D) study. Children (aged 7-17 years) 
were assessed psychiatrically at the study's inception and three months by a team of blinded evaluators. Those children who were free of any psychiatric symptoms at the inception of the study and whose mothers' depression remitted with treatment remained well, while $17 \%$ of initially well children whose mothers did not remit acquired a psychiatric disorder (depressive, anxiety, or disruptive behavior disorders). Successful treatment to remission of maternal depression was associated with an $11 \%$ decrease in rates of diagnosis for their children; whereas failure to remit resulted in an $8 \%$ increase in psychiatric diagnoses in their children. These results suggest that successful treatment of maternal depression has a positive effect on the mental well-being of their school-aged children. As a corollary of this data, a twentyyear follow-up study of adult offspring of depressed parents revealed that they had higher rates of depression, anxiety, substance dependence, work dysfunction, family dysfunction, and physical illness (especially cardiovascular disease) than age-matched offspring of non-depressed parents $(55,56)$.

Perhaps one of the most notable consequences of untreated antenatal depression is the subsequent increase in risk for postpartum depression (57). Postpartum depression is another extremely severe form of perinatal mental illnesses, occurring together with one or more complications such as poor weight gain, suicide, sleep problems, less breastfeeding, poor attachment, infanticide, and increased health care costs $(48,52)$.

\section{Data Sources and Interpretation}

In this section we will discuss the strengths and weakness of the various forms of research based on suggestions about teratogenicity.

Case reports: The first data about teratogens usually originated from case reports. If a case reports exert a specific abnormality that is well described in similar drug exposure, in certain time of fetal or embryonic period, they are useful. Case reports cannot make accurate analysis of abnormality risk. If a defect and exposure occurs more frequently in a pregnant woman, coincidence is unavoidable. Case reports must be cautiously interpreted in order to establish a causal link between exposure to a particular medication (58).

Case series: Several cases can exist, up to hundreds or more. The main limitation of a case series is that there is no control group, so the results cannot be compared to a group representing the population. The sample size of studies assessing the safety of these medications in pregnancy usually is statistically small. Almost 800 cases in each treatment group would be required to detect a two fold increased risk, and thousands of cases would be required to detect rare defects (59).

Epidemiological investigations used in teratology are primarily of two types: cohort studies and casecontrol studies. In prospective comparative cohort studies, exposures of interest are identified and a prospective follow up of women are enrolled in the study. Following birth of the baby, pregnancy outcomes are obtained and compared with other women who were not exposed to the drug in question. In retrospective case control studies, the outcome is known and the group is compared to another group who were born with the same birth defects. The two groups are then matched on important variables and a search is conducted for evidence of exposure. The point worth emphasizing is that epidemiological studies provide only the means of obtaining quantitative estimates regarding the strength and statistical significance of associations between agent exposures in pregnant women and abnormalities in their children. When doing interpretation for epidemiological studies, one must remember that the maternal disease or situation, which occasioned the exposure rather than the agent itself, may be responsible for an observed association. A statistically significant association in an epidemiological study is never assumed to indicate causality without other evidence to support such a conclusion. Moreover, etiological heterogeneity of human congenital abnormalities or the subtle patterns of anomalies characteristic of many human teratogens limit the usefulness of most published epidemiological studies (58).

Meta-analysis: Since most observational pregnancy outcome studies have small sample sizes, this method is very useful when studying drug use in pregnancy. Combining results across different studies, enlarging the sample size makes a more definitive statement regarding safety/risk of the drug are possible with meta-analysis. Firstly, a literature search is conducted using all available databases including case-control and cohort studies and abstracts presented at scientific meetings which subjects 
were similar. The inclusion and exclusion process is carried out. The reviewers then extract the data from the included studies into $2 \times 2$ tables and the data are analyzed (58).

Administrative data base studies: Databases are not typically set up for pharmacoepidemiological research as they are primarily developed for various administrative claims payment. For this reason, important data is often missing, especially for studies of drug use and pregnancy outcomes. However, they often contain large numbers of individuals with important information so they have been increasingly used in research, most frequently to conduct post-marketing surveillance. Some registries are driven by pharmaceutical companies (often compelled by national or international drug licensing agencies) and provide data on pregnancy outcome related to the sponsor's own product. Others are organized by independent research groups and they can be more useful as comparative data is used. The major strength of these registries is that often they will contain prospective data, although some do report on retrospective data, they often contain large numbers of exposed women and can be run for several years (58).

Prescription data base studies: Compiled with data from prescriptions that have been filled by the patient. The main strength of this method is the very large sample sizes.

National birth registries: Some countries, mostly in Europe, operate registries where the mother and child pairs are entered after birth and are followed up prospectively.

If we compare these methods according to evidencebased medicine, well-designed cohort or case-control analytical studies are more acceptable than one center or research group researches. Actually, in determination of teratogenecity and toxicity the most valuable source is prospective, randomized, double-blind, placebo controlled studies. Unfortunately they are impossible to conduct during pregnancy. Therefore data must be cautiously interpreted especially when we have conflicting studies.

\section{CONCLUSION}

Many clinicians avoid prescribing for fear of possible adverse effects on the pregnancy outcome, neonatal symptoms, and long-term effects. Although some studies report that antidepressant use during pregnancy is related to congenital malformations, negative birth outcome, and neurodevelopmental problems, there are conflicting results. None of them showed so far a clear link between attributed adverse effects and antidepressant use during pregnancy. Also, it is clear that none of psychotropic medications is fully devoid of risks for pregnancy. On the other hand, it is irresponsible to leave severely depressed women who are irresponsive to psychotherapy, or have some difficulties to attend psychotherapy, untreated, even if pregnant. The risks of untreated depression during pregnancy to the mother and the fetus (eg, preterm delivery, poor nutrition, inadequate weight gain, poor prenatal care, inability to care for oneself, substance use, termination of the pregnancy, and postpartum depression) also deserve attention. Antenatal depression is significant not only because of its prevalence but also because of its consequences. Depression can impair the mother's nutritional intake and prenatal care, increase her likelihood of using potentially harmful addictive substances, and lead to suicide attempts. Depression during pregnancy is a strong predictor of postpartum depression, a condition that can have direct consequences for the mother, the baby, and the entire family. Therefore, it could be argued that nothing is more critical than sustaining maternal emotional well-being during pregnancy. On the other hand, current knowledge has been based on several sources of data like case reports, retrospective and prospective studies, and animal experiments. Therefore, determination of any possible adverse outcome requires careful evaluation of data coming from various sources.

In conclusion, clinicians should try to find the safest option and should pay attention to the risks of both medications and untreated depression. In decisionmaking, clinicians and families must weigh the risks of untreated or undertreated depression. Further, the field needs to better understand the mechanisms by which problematic outcomes occur, with exposure to antidepressants or exposure to depression.

\section{Acknowledgement}

The authors thanks to Mr. Cooper Howland for his comments and criticisms. 


\section{References:}

1. Bennett HA, Einarson A, Taddio A, Koren G, Einarson TR. Prevalence of depression during pregnancy: systematic review. Obstet Gynecol 2004;103:698-709.

2. Cohen L, Altshuler L. Pharmacologic management of psychiatric illness during pregnancy and the postpartum period. In: Dunner D, Rosenbaum J (editors). The Psychiatric Clinics of North America Annual of Drug Therapy. Philadelphia: WB Saunders Company, 1997: 21-60.

3. McBride W. Limb deformities associated with iminodibenzyl hydrochloride [letter]. Med J Aust 1972; 1: 492.

4. Alwan S, Reefhuis J, Rasmussen SA, Olney RS, Friedman JM. Use of selective serotoninreuptake inhibitors in pregnancy and the risk of birth defects. National Birth Defects Prevention Study. N Engl J Med 2007; 28;356:2684-92.

5. Louik C, Lin AE, Werler MM, Hernández-Díaz S, Mitchell AA. Firsttrimester use of selective serotonin-reuptake inhibitors and the risk of birth defects. N Engl J Med 2007; 28;356:2675-83.

6. Glaxo Smith Kline study EPIP083. GSK medicine: bupropion and paroxetine. Epidemiology study: preliminary report on bupropion in pregnancy and the occurrence of cardiovascular and major congenital malformation. Available:http://ctr.gsk.co.uk/ summary/paroxetine/epip083.pdf).

7. Malm H, Artama M, Gissler M, Ritvanen A. Selective Serotonin Reuptake Inhibitors and Risk for Major Congenital Anomalies. Obstet Gynecol 2011;118:111-20.

8. Källén BA, Otterblad Olausson P. Maternal use of selective serotonin re-uptake inhibitors in early pregnancy and infant congenital malformations. Birth Defects Res A Clin Mol Teratol 2007; 79:301-8.

9. Oberlander TF, Misri S, Fitzgerald CE, Kostaras X, Rurak D, Riggs W. Pharmacologic factors associated with transient neonatal symptoms following prenatal psychotropic medication exposure. J Clin Psychiatry 2004; 65: 230-7.

10. Zeskind PS, Stephens LE. Maternal selective serotonin reuptake inhibitor use during pregnancy and newborn behaviour. Pediatrics 2004; 113:368-75.

11. Chambers CD, Hernandez-Diaz S, Van Marter LJ, Werler MM, Louik C, Jones KL, Mitchell AA. Selective serotonin reuptake inhibitors and risk of persistent pulmonary hypertension of the newborn. N Engl J Med 2006; 9;354:579-87.

12. Jetter A. Pregnant Pause. Vogue 2009; 232:144-148.

13. Casper RC, Fleisher BE, Lee-Ancajas JC, Gilles A, Gaylor E, DeBattista A, Hoyme HE. Follow-up of children of depressed mothers exposed or not exposed to antidepressant drugs during pregnancy. J Pediatr 2003; 142: 402-8.

14. Oberlander TF, Grunau RE, Fitzgerald C, Papsdorf M, Rurak D, Riggs W. Pain reactivity in 2-month-old infants after prenatal and postnatal serotonin reuptake inhibitor medication exposure. Pediatrics 2005; 115: 411-25.

15. Maciag D, Simpson KL, Coppinger D, Lu Y, Wang Y, Lin RC, Paul IA. Neonatal antidepressant exposure has lasting effects on behavior and serotonin circuitry. Neuropsychopharmacology 2006; 31:47-57.
16. Croen LA, Grether JK, Yoshida CK, Odouli R, Hendrick V. Antidepressant Use During Pregnancy and Childhood Autism Spectrum Disorders. Arch Gen Psychiatry 2011 [Epub ahead of print].

17. Portnoi G, Chng LA, Karimi-Tabesh L, Koren G, Tan MP, Einarson A. Prospective comparative study of the safety and effectiveness of ginger for the treatment of nausea and vomiting in pregnancy. Am J Obstet Gynecol 2003; 189:1374-7.

18. McElhatton PR, Garbis HM, Eléfant E, Vial T, Bellemin B, Mastroiacovo P, Arnon J, Rodríguez-Pinilla E, Schaefer C, Pexieder T, Merlob P, Dal Verme S. The outcome of pregnancy in 689 women exposed to therapeutic doses of antidepressants. A collaborative study of the European network of teratology information services (ENTIS). Reprod Toxicol 1996; 10:285-94.

19. Altshuler LL, Cohen L, Szuba MP, Burt VK, Gitlin M, Mintz J. Pharmacologic management of psychiatric illness during pregnancy: dilemmas and guidelines. Am J Psychiatry 1996 May;153:592-606.

20. Briggs GG, Freeman RK, Yaffe SJ. Drugs in pregnancy and lactation. $6^{\text {th }}$ ed. Philadelphia, PA: Lippincott Williams \& Wilkins; 2002. p. 319-20.

21. Kalra S, Einarson A. Prevalence, Clinical Course, and Management of Depression During Pregnancy. In: Psychiatric Disorders in Pregnancy and the Postpartum Principles and Treatment. Hendrick V, Ed, Humana Press, 2006 p.13-40.

22. Pastuszak AL, Schick-Boschetto B, Zuber C, Feldkamp ML, Pinelli M, Sihn S, Donnenfeld A, McCormack M, Leen-Mitchell M, Woodland C, Gardner A, Horn G, Koren G. 1993. Pregnancy Outcome following First-Trimester Exposure to Fluoxetine (Prozac). JAMA 269:2246-2248

23. Goldstein DJ. Effects of third trimester fluoxetine exposure on the newborn. J Clin Psychopharmacol 1995; 15:417-20.

24. Goldstein DJ, Corbin LA, Sundell KL. Effects of first-trimester fluoxetine exposure on the newborn. Obstet Gynecol 1997; 89:713-8.

25. Hendrick V, Smith LM, Suri R, Hwang S, Haynes D, Altshuler L. Birth outcomes following prenatal exposure to antidepressant medications. Am J Obstet Gynecol 2003; 188:812-5.

26. Simon GE, Cunningham ML, Davis RL. Outcomes of prenatal antidepressant exposure. Am J Psychiatry 2002; 159:2055-61.

27. Kulin NA, Pastuszak A, Sage SR, Schick-Boschetto B, Spivey G, Feldkamp M, Ormond K, Matsui D, Stein-Schechman AK, Cook L, Brochu J, Rieder M, Koren G. Pregnancy outcome following maternal use of the new selective serotonin reuptake inhibitors: a prospective controlled multicenter study. JAMA 1998; 279:609-10.

28. Costei AM, Kozer E, Ho T, Ito S, Koren G. Perinatal outcome following third trimester exposure to paroxetine. Arch Pediatr Adolesc Med 2002; 156: 1129-32.

29. Heikkinen T, Ekblad U, Kero P, Ekblad S, Laine K. Citalopram in pregnancy and lactation. Clin Pharmacol Ther 2002; 72: 184-91.

30. Einarson A, Fatoye B, Sarkar M, Lavigne SV, Brochu J, Chambers C, Mastroiacovo P, Addis A, Matsui D, Schuler L, Einarson TR, Koren G. Pregnancy outcome following gestational exposure to venlafaxine: a multicenter prospective controlled study. Am J Psychiatry 2001; 158:1728-30. 
31. Chun-Fai-Chan B, Koren G, Fayez I, Kalra S, Voyer-Lavigne S, Boshier A, Shakir S, Einarson A. Pregnancy outcome of women exposed to bupropion during pregnancy: a prospective comparative study. Am J Obstet Gynecol 2005; 192:932-6.

32. Nulman I, Rovet J, Stewart DE, Wolpin J, Pace-Asciak P, Shuhaiber S, Koren G. Child development following exposure to tricyclic antidepressants or fluoxetine throughout fetal life: a prospective, controlled study. Am J Psychiatry 2002; 159:1889-95.

33. Nulman I, Rovet J, Stewart DE, Wolpin J, Gardner HA, Theis JG, Kulin N, Koren G. Neurodevelopment of children exposed in utero to antidepressant drugs. N Engl J Med 1997; 23:336: 258-62.

34. Rosenbaum JF, Zajecka J. Clinical management of antidepressant discontinuation. J Clin Psychiatry 1997;58:37-40.

35. Cohen LS, Altshuler LL, Harlow BL, Nonacs R, Newport DJ, Viguera AC, Suri R, Burt VK, Hendrick V, Reminick AM, Loughead A, Vitonis AF, Stowe ZN. Relapse of major depression during pregnancy in women who maintain or discontinue antidepressant treatment. JAMA 2006; 1:295:499-507.

36. Marcus SM, Flynn HA. Depression, antidepressant medication, and functioning outcomes among pregnant women. Int J Gynaecol Obstet 2008;100:248-51.

37. Van den Hove DL, Steinbusch HW, Scheepens A, Van de Berg WD, Kooiman LA, Boosten BJ, Prickaerts J, Blanco CE. Prenatal stress and neonatal rat brain development. Neuroscience 2006; 137, 145155.

38. Flynn HA, Chermack ST. Prenatal alcohol use: the role of lifetime problems with alcohol, drugs, depression, and violence. J Stud Alcohol Drugs 2008; 69:500-9.

39. Marcus SM, Flynn HA, Blow FC, Barry KL. Depressive symptoms among pregnant women screened in obstetrics settings. J Womens Health (Larchmt) 2003;12: 373-80.

40. Kelly RH, Russo J, Holt VL, Danielsen BH, Zatzick DF, Walker E, Katon W. Psychiatric and substance use disorders as risk factors for low birth weight and preterm delivery. Obstet Gynecol 2002; 100:297-304.

41. Steer RA, Scholl TO, Hediger ML, Fischer RL. Self-reported depression and negative pregnancy outcomes. J Clin Epidemiol 1992; 45:1093-9.

42. Miller LJ. Clinical strategies for the use of psychotropic drugs during pregnancy. Psychiatr Med 1991;9: 275-98.

43. Zuckerman B, Bauchner H, Parker S, Cabral H. Maternal depressive symptoms during pregnancy, and newborn irritability. J Dev Behav Pediatr 1990;11:190-4.

44. Schmeelk KH, Granger DA, Susman EJ, Chrousos GP. Maternal depression and risk for postpartum complications: role of prenatal corticotropin-releasing hormone and interleukin-1 receptor antagonist. Behav Med 1999; 25:88-94.
45. Bansil P, Kuklina EV, Meikle SF, Posner SF, Kourtis AP, Ellington SR, Jamieson DJ. Maternal and Fetal Outcomes Among Women with Depression. J Womens Health (Larchmt) 2010; 19:329-34.

46. Kurki T, Hiilesmaa V, Raitasalo R, Mattila H, Ylikorkala O. Depression and anxiety in early pregnancy and risk for preeclampsia. Obstet Gynecol 2000; 9:487-90.

47. Hoffman S, Match MC. Depressive symptomatology during pregnancy: Evidence for an association with decreased fetal growth in pregnancies of lower social class women. Health Psychol Bull 2000:535-43.

48. Lundy B, Jones N, Field T, Nearing G, Davalos M, Pietro P,Schanberg S, Kuhn C: Prenatal depression effects on neonates. Infant Behav Dev 1999; 22:119-129

49. Bonari L, Bennett H, Einarson A, Koren G. Risks of untreated depression during pregnancy. Can Fam Physician 2004; 50:37-9.

50. Field T, Diego MA, Dieter J, Hernandez-Reif M, Schanberg S, Kuhn C, Yando R, \& Bendell D. Depressed, withdrawn and intrusive mothers' effects on their fetuses and neonates. Inf Behav and Dev 2001:27-39.

51. Chung TK, Lau TK, Yip AS, Chiu HF, Lee DT. Antepartum depressive symptomatology is associated with adverse obstetric and neonatal outcomes. Psychosom Med 2001; 63:830-4.

52. Lundy B, Field T. Newborns of mothers with depressive symptoms are less expressive. Infant Behav Dev 1996; 19; 419-424.

53. Hay DF, Pawlby S, Waters CS, Sharp D. Antepartum and postpartum exposure to maternal depression: different effects on different adolescent outcomes. J Child Psychol Psychiatry 2008; 49(10):1079-88.

54. Hay DF, Pawlby S, Waters CS, Perra O, Sharp D. Mothers' antenatal depression and their children's antisocial outcomes. Child Dev 2010; 81:149-65.

55. Weissman MM, Pilowsky DJ, Wickramaratne PJ, Talati A, Wisniewski SR, Fava M, Hughes CW, Garber J, Malloy E, King CA, Cerda G, Sood AB, Alpert JE, Trivedi MH, Rush AJ; STAR*D-Child Team. Remissions in maternal depression and child psychopathology, a STAR*D-Child Report. JAMA 2006; 22;295:1389-98.

56. Weissman MM, Wickramaratne P, Nomura Y, Warner V, Pilowsky D, Verdeli H. Offspring of depressed parents: 20 years later. Am J Psychiatry 2006; 163:1001-8.

57. Beck, CT. Revision of the postpartum depression predictors inventory. J Obstet Gynecol Neonatal Nurs 2002; 31: 394-402.

58. TERIS.The Teratogen Information system. (www.depts. washington.edu/terisweb/teris/Preamble.htm)

59. Einarson A. Reproductive Mental Health-Motherrisk Update 2008 Risks/Safety of Psychotropic Medication use during Pregnancy. Can J Clin Pharmacol 2009;16, 1:1-67. 